\title{
BENCANA, PERLINDUNGAN SOSIAL, DAN PEREMPUAN: Studi Kasus Pasca Erupsi Merapi Di Yogyakarta
}

\author{
Ashadi Cahyadi* \\ E-mail: ashadicahyadi@iainbengkulu.ac.id
}

\begin{abstract}
Abstrak
Indonesia sebagai negara yang memiliki potensi bencana besar membutuhkan banyak diskusi dari pengalaman masa lalu. Studi ini membahas tentang strategi pemerintah, komunitas, dan masyarakat dalam membangkitkan sektor ekonomi pasca erupsi merapi di Yogyakarta. Penulis memberikan perhatian khusus pada pemberdayaan perempuan karena dianggap sebagai subyek rentan. Studi ini menggunakan metode kualitatif yang didukung oleh beberapa data yang bersifat kuantitatif. Semua bahan dipelajari secara interaktif, direduksi, kemudian intisari bacaan dikembangkan sesuai penalaran induktif. Studi ini menemukan bahwa pada awal bencana, perlindungan sosial menjadi strategi utama yang harus dilakukan. Itu berupa bantuan sosial, asuransi sosial, kebijakan pasar kerja, dan jaringan pengamanan sosial berbasis masyarakat. Kemudian, masa recovery yang telah diisi oleh perlindungan sosial harus dilanjutkan ke tahap pemberdayaan sosial. Model pendampingan menjadi strategi yang paling idel dan rasional ketika masyarakat berada pada kondisi lower classyang hanya bisa menggantungkan nasib pada negara dan swasta.
\end{abstract}

Kata Kunci : Perlindungan sosial, pemberdayaan sosial, manajemen bencana, perempuan.

\section{Pendahuluan}

Tulisan ini melanjutkan pembahasan dari artikel yang ditulis oleh Farsijana Adeney-Risakotta, berjudul “Menguraikan Kemiskinan Pasca Bencana Merapi". Penulis akan mencoba mengkaji lebih dalam tentang akibat bencana erupsi merapi tahun 2010 di Yogyakarta dengan menggunakan teori-teori pembangunan yang ada. Dari artikel Farsijana, penulis dapat menyimpulkan tiga point penting, yakni: 1) terdapat perbedaan data dan pandangan tentang kemiskinan yang diakibatkan bencana erupsi merapi. Pandangan tersebut mengidikasikan bahwa pemerintah mengkaji kemiskinan secara makro (melalui data kuantitatif), sedangkan lembaga ESEI mengidentifikasi masalah kemiskinan secara kualitatif atau mikro; 2) korban bencana erupsi merapi mengalami kemiskinan yang merata, ini mengindikasikan ketergantungan yang luar biasa dalam segala bidang kehidupan; karenanya 3) dibutuhkan program pemberdayaan masyarakat pasca bencana di tingkat mikro untuk mempercepat pemulihan kehidupan masyarakat pasca erupsi merapi.

Dalam pembahasan ini akan dibangun argumen bahwa pembangunan yang berkelanjutan (suistainable development)mungkin akan tercapai ketika 
kebijakan pembangunan dimulai dari pemberdayaan pada subjek pembangunan. Tanpa mengabaikan unsur pembangunan lain seperti pembangunan infrastruktur, paper ini optimistis bahwa pembangunan pasca bencana harus dimulai dari pembangunan yang berbasis manusia (people centred development). Akan dijelaskan lebih lanjut tentang perubahan sosial pasca erupsi Merapi, kemudian dilanjutkan dengan pemberdayaan melalui langkah konkrit pendampingan sosial, dan terakhir melihat pembangunan yang berwawasan gender.

Sejatinya, pembangunan dan bencana adalah dua fenomena yang saling bertentangan, karena yang pertama bermakna positif sedang yang kedua bermakna negatif. Akan tetapi, kedua istilah ini selalu berjalan berhimpitan di mana dalam setiap pembangunan akan ada kemungkinan munculnya sebuah bencana, sebaliknya sebuah bencana akan menuntut sebuah proses pembangunan. Ketika bencana menjadi ancaman serius, orang makin sadar bahwa investasi pembangunan dinihilkan karena bencana akan menegasikan seluruh proses dan hasil pembangunan yang sudah dilakukan.

Satu narasi menyedihkan yang disampaikan oleh ibu Senen, isteri Kadus Kalitengah Lor, yang memiliki \pm 20 ekor 96 sapi baik yang dipelihara sendiri ataupun digaduhkan kepada tetangga, semuanya musnah. Rumah, kebun, mobil, semua hartanya habis dilahap wedus gembel (awan panas merapi) kecuali yang tersisa hanya pakaian yang melekat di badan. ${ }^{1}$ Narasi ini mengindikasikan bahwa pembangunan tidak bisa dipisahkan dari bencana sebab "kita hidup berdampingan dengan bencana"2 dan keberhasilan pembangunan berkelanjutan (sustainable development) sangat tergantung pada kemampuan bangkit dari keterpurukan dan belajar mengurangi risiko bencana. ${ }^{3}$

Tulisan ini membahas beberapa isu penting terkait fenomena yang ditimbulkan oleh bencana erupsi merapi, antara lainbagaimana teori perubahan sosial dan pembangunan alternatif mampu mengurai masalah kemiskinan yang tengah dihadapi pasca erupsi merapi? Bagaimana pendampingan sosial mampu menjadi daya tawar atas permasalahan pembangunan warga miskin paska erupsi merapi? Kemudianbagaimana sumbangan perspektif genderdalam pembangunan pasca erupsi merapa di Yogyakarta?

\section{A. Perubahan Sosial dan Model Pembangunan Alternatif}

Memahamai dampak erupsi Merapi bagi masyarakat melalui pendekatan 
perubahan sosial adalah salah satu cara untuk mendapatkan kejelasan substansi wawasan konkrit dan ancangan empiris sesuai keluasan pendekatan dengan ruang yang cukup untuk berkembang dan mewujudkan tujuan pengkajian. Dalam pemahaman kaum strukturalis, perubahan sosial memang selalu datang dari unsur luar masyarakat.4Tatanan sosial yang awalnya membuat masyarakat nyaman dan berinteraksi dengan baik, harus berubah karena masuknya faktor eksternal. Bencana alam yang merubah struktur kehidupan masyarakat, dapat dikatakan sebagai akibat dari faktor eksternal. Di satu sisi, bencana dan strukturalis memiliki hubungan causeseffect, tapi di sisi lain, keduanya dapat saling meniadakan karena tidak pernah masuk dalam pembahasan para pakar strukturalis seperti Raul Prebisch, Furtando, Dos Santos, maupun Paul Baran.

Meminjam pemikiran Marvin Harris (1979) berdasarkan pemikiran strukturalis dari Levi-Strauss yang menjelaskan perubahan sosial masyarakat melalui tiga struktur, yakni diawali pada perubahan struktur ekonomi (Material Infra-Structure), diikuti oleh Sosial Structure dan kemudian sampai pada Ideological Super-Structure. ${ }^{5}$ Perubahan sosial yang paling jelas pasca erupsi adalah perubahan pada struktur ekonomi. Telah terjadi kemiskinan massal pada korban bencana Merapi. Warga yang semula tidak masuk dalam kelompok masyarakat miskin, pasca erupsi Merapi, kelompok ini menjadi kelompok miskin baru karena sumber daya yang semua dimiliki rusak dan hilang. Masyarakat yang memiliki struktur ekonomi baru ini terletak di desa Kinahrejo, Petung, Balerante, Kalirejo, Gondang, dan 28 desa lainnya.

Dari data yang dikeluarkan oleh pemkab sleman, terdapat 67.852 orang pengungsi yang tersebar di berbagai daerah Yogyakarta dan Jawa Tengah, 276 orang meninggal hingga data ditetapkan tanggal 2 desember 2010. 2.586 rumah rusak, daerah yang terparah adalah Kecamatan Cangkringan yang kemudian disusul oleh Kecamatan Turi. Dalam hitungan manual, jika dalam satu rumah terdapat tiga orang, berarti akan ada sekitar 7.500 orang miskin baru yang siap menggantungkan nasib pada pemerintah dan swasta. Artinya secara struktur sosial, mereka akan berada pada strata yang paling bawah (lower-lower class). Upaya yang paling baik sejauh ini untuk mengangkat struktur sosial mereka adalah dengan pemberdayaan yang memanfaatkan skill masing-masing individu. Sedangkan Ideological SuperStructure belum akan terbentuk karena 
Harris menyebutkan perubahan ini tergantung pada refleksi dari dua struktur yang ada di atasnya, tergantung pada dinamika yang bersifat structural yang digerakkan oleh unsur ekonomi yang bersifat materialis.

Tabel 1 Data Kerusakan Rumah di Tiga Desa Diekstrak dari situs Pemkab Sleman

\begin{tabular}{|l|l|c|c|c|}
\hline $\mathbf{N}$ & $\begin{array}{c}\text { Kecamata } \\
\mathbf{n}\end{array}$ & $\begin{array}{c}\text { Jumlah } \\
\text { Desa }\end{array}$ & $\begin{array}{c}\text { hus } \\
\mathbf{\text { Dusu }} \\
\mathbf{n}\end{array}$ & $\begin{array}{c}\text { Kerusak } \\
\text { an } \\
\text { Rumah }\end{array}$ \\
\hline 1 & $\begin{array}{l}\text { Cangkrin } \\
\text { gan }\end{array}$ & 5 & 31 & 2.555 \\
\hline 2 & Turi & 4 & 6 & 6 \\
\hline 3 & $\begin{array}{l}\text { Ngempla } \\
\text { k }\end{array}$ & 1 & 25 \\
\hline \multicolumn{4}{|c|}{ Total } & 2.586 \\
\hline
\end{tabular}

Sumber: www.slemankab.go.id

Dalam kondisi yang sangat nisbi, strategi yang paling rasional untuk mengatasi kelompok lower-lower class ini adalah dengan perspektif pembangunan kesejahteraan sosial dan pekerjaan sosial berupa perlindungan sosial (social protection). Perlindungan sosial adalah skema yang dirancang secara terencana oleh pemerintah maupun masyarakat untuk melindungi anggotanya dari berbagai risiko dalam kehidupan, baik risiko yang timbul dari diri sendiri (kecelakaan, sakit, meninggal dunia), maupun yang timbul dari lingkungan (mengganggur, bencana alam/sosial). ${ }^{6}$ Berikut hasil analisa yang dilakukan pemerintah dalam mengatasi kelompok yang terkena dampak bencana:

a. Bantuan sosial. Skema jaminan sosial (social security) yang berbentuk tunjangan uang, barang, atau pelayanan kesejahteraan yang umumnya diberikan berdasarkan “tingkat kemiskinan" tanpa memperhatikan kontribusi sebelumnya (prior contribution). Mutlak setelah bencana alam, bantuan sosial menjadi bantuan yang paling utama diberikan kepada para korban.

b. Asuransi Sosial. Skema jaminan sosial yang hanya diberikan pemerintah kepada kelompok lowerlower class, yang seluruh harta bendanya musnah. Sistem asuransi yang diberikan berupa asuransi kesehatan, rumah, dan pemberian uang tunai secara berkala. Seperti yang diberikan Mentri Sosial, Salim Segaf Al-Jufri, berupa Jadup (Jaminan Hidup) Rp. 5.000,- perhari.

c. Kebijakan pasar kerja (labour market policies). Pekerjaan adalah bentuk perlindungan sosial yang berkelanjutan. Kebijakan pasar kerja 
merupakan kebijakan publik untuk meregulasi dunia kerja yang dapat menstabilkan perekonomian masyarakat. Pemerintah melakukan kebijakan ini untuk mengurangi ketergantungan masyarakat pada dana Jadup. Dana Jadup yang telah diberikan selama 11 bulan dan diperpanjang hingga bulan Desember 2011 dinilai mempersulit pemberdayaan masyarakat. Karena itu, melalui 20 paket program padat karya, korban bencana mulai dilatih untuk berdikari dan membangun kembali ekonomi.

d. Mekanisme dan jaringan pengamanan sosial berbasis masyarakat (local community based development). Sejak berabad yang lalu, Indonesia sudah kaya dengan budaya dan inisiatif lokal dalam merespon dan kebutuhan sendiri dan kelompok. Di pedesaan, modal sosial dapat dijadikan basis awal dalam menyelenggarakan kegiatan ekonomi, sosial, dan budaya seperti arisan, raksa desa, siskamling, kelompok pengajian, kelompokdana kematian, bahkan dibeberapa tempat seperti di Cangkringan terlihat masyarakat secara swadaya membangun desa wisata sisa erupsi merapi. Prinsip partisipatif dan egaliter dalam menyelenggarakan ekonomi dan sosial secara lambat laun mengembalikan siklus ekonomi-sosial masyarakat yang dulu hilang.

Dengan demikianyang telah dilakukan pemerintah, swasta, dan masyarakat korban bencana sejalan dengan perspektif pembangunan alternatif (alternative development). Ada saatnya negara berperan aktif (active state) dalam membangun kembali kehidupan masyarakat. Pada saat yang lain, pemerintah mencoba melepaskan diri (weak state) sebagai bentuk pemberdayaan masyarakat dan keharusan masyarakat untuk melepaskan diri dari ketergantungan.

Pada pembangunan alternatif di atas, kita juga dapat melihat adanya perpaduan dua perspektif besar, yakni perspektif neo-liberal dan perspektif demokrasi sosial. Kedua hal ini apabila digabungkan, akan menimbulkan sebuah sintesis baru yang berdampak luar biasa bagi pembangunan kembali peradaman manusia. Selain mencakup programprogram yang bersifat residual, perlindungan sosial juga meliputi program-program sosial yang berproses pada pendekatan institusional. ${ }^{7}$ 
B. Pemberdayaan Masyarakat Sebagai Variabel Pembangunan Pasca Erupsi

\section{Merapi}

Menurut Arief Budiman bahwa ukuran pencapaian hasil pembangunan paling tidak mencapai lima unsur yang dapat dilihat secara objektif, antara lain: ${ }^{8}$

a. Pembangunan pada awalnya dilihat dalam kerangka pertumbuhan ekonomi masyarakat di suatu negara. Pembangunan akan berhasil, dengan indikator pertumbuhan ekonomi masyarakat cukup tinggi, diukur dari produktivitas masyarakat dan negara disetiap tahun. Secara teknis ekonomis, produktivitas diukur oleh Gross National Product (GNP) dan Gross Domestic Product (GDP).

b. Dicapainya pemerataan disuatu masyarakat dalam suatu negara. Ukuran yang dilakukan adalah memahami perhitungan indeks gini, yang dapat mengukur adanya ketimpangan pembagian pendapatan masyarakat. Negara yang berhasil pembangunanya dengan demikian adalah negara yang produktivitasnya tinggi, penduduknya makmur dan sejahtera secara relatif.

c. Kualitas kehidupan yang diukur dari tingkat kesejahteraan penduduk disuatu negara dengan menggunakan tolak ukur PQLI (Physical Quality of Life Index) yang berasal dari tiga indikator, meliputi:

i. Angka rerata harapan hidup bayi setelah satu tahun;

ii. Angka rerata jumlah kematian bayi;

iii. Angka rerata melek huruf masyarakat.

d. Kerusakan lingkungan hidup harus pulsa diperhitungkan. Negara yang tinggi produktivitasnya, dapat berada pada sebuah proses pemiskinan penduduknya. Hal itu bisa terjadi karena produktivitasnya yang tinggi tidak memperdulikan dampak terhadap kerusakan lingkungan. Lingkungan hidup semakin rusak, sumber daya terkuras, berbanding terbalik dengan daya alam untuk memperbaharui diri. pabrik-pabrik memang meningkatkan pendapatan, tetapi mereka juga menghasilkan limbah kimia yang merusak alam sekitar. Pembangunan seperti ini ternyata tidak sustainable.

e. Pembangunan harus berorientasi pada keadilan dan kesinambungan. Pembangunan yang sedang berlangsung seringkali menimbulkan ketimpangan yang 


\section{Ashadi Cahyadi \\ BENEANA, PERLINDLINGAN SDSIAL, DAN PEREMPLAN}

sangat mencolok dalam masyarakat.

Pembangunan menciptakan gap anatar si kaya dengan si miskin. Kondisi ini jelas menimbulkan kerawanan bagi negara. Oleh karena itu konfigurasi kekuatan sosial disuatu masyarakat mengarah kepada kemungkinan pertentangan yang semakin menajam.

Jika pembangunan adalah sebuah perencanaan sosial (social plan) yang berujung pada kesejahteraan seluruh lapisan masyarakat, maka kelima indikator ini bersifat fleksibel. Tidak ada sebuah keharusan untuk menentut satu negara mengikuti kelima indikator ini. Salim menyebutkan bahwa negara tidak harus mengikuti indikator-indikator pembangunan, karena tiap negara memiliki perbedaan karakteristik. ${ }^{9}$ Terpenting adalah bagaimana sebuah masyarakat menjadi sejahtera secara menyeluruh. Begitu juga untuk kasus erupsi merapi yang tengah dialami oleh korban di kecamatan Cangkringan, Turi, dan Ngemplak. Bencana besar yang melanda desa mereka, menjadikan mereka hidup bergantung pada orang lain. Tidak ada pilihan lain, selain menerima bantuan dari masyarakat yang tidak terkena dampak. Pertanyaan kemudian yang muncul adalah sampai kapan mereka menggantungkan hidup pada orang lain?
Jika pertanyaan ini direnungkan, akan muncul konsekuensi berupa apa yang bisa korban erupsi lakukan dengan kemampuan yang serba terbatas? Maka pembangunan yang paling ideal dan rasional saat ini adalah memberdayakan masyarakat.

Sampai sejauh ini, pemberdayaan masyarakat belum menjadi indikator penilaian majunya sebuah negara. Pada tataran konsep, pemberdayaan masyarakat menuai sikap optimisme, tetapi dalam praktik pembangunan dinilai tidak berjalan mulus. Banyak pemikir dan praktisi yang meragukan praktik pemberdayaan sebagai alternatif pemecahan terhadap dilema-dilema pembangunan yang berorientasi pada manusia (people-centred). Akan tetapi, sebagai sebuah strategi pembangunan model ini telahmendapat pengakuanoleh Konferensi Tingkat Tinggi (KTT) di Kopenhagen tahun 1992 tentang Pembangunan Sosial.

Pemberdayaan masyarakat mencerminkan model pembangunan yang bersifat "people-centered, participatory, empowering, and sustainable."10 Model ini bisa sebagai antitesis terhadap model pembangunan yang kurang memihak pada masyarakat kelas bawah yang menjadi mayoritas di negara-negara dunia Ketiga. Konsep ini terbangun dari 
kerangka logik sebagai berikut: (1) faktor produksi terbangun dari pemusatan kekuasaan; (2) pemusatan kekuasaan faktor produksi akan melahirkan masyarakat pekerja dan masyarakat pengusaha pinggiran; (3) kekuasaan akan membangun bangunan atas atau sistem pengetahuan, sistem politik, sistem hukum dan sistem ideologi yang manipulatif untuk memperkuat legitimasi; dan (4) pelaksanaan sistem pengetahuan, sistem politik, sistem hukum dan ideologi secara sistematik akan menciptakan dua kelompok masyarakat, yaitu masyarakat berdaya dan masyarakat tunadaya. ${ }^{11}$ Sejalan dengan itu, Ife menjelakan bahwa pemberdayaan memuat dua pengertian kunci, yakni kekuasaan dan kelompok lemah.12 Pemberdayaan masyarakat akan meniadakan kekuasaan dan menggunakan potensi dari kelompok lemah itu sendiri.

Dalam kasus korban erupsi merapi yang mengalami kemiskinan pada taraf paling bawah (lower-lower class), hingga masyarakat tidak memiliki apapun selain menunggu program Jadup Rp. 5.000 perhari, maka pemberdayaan harus dilakukan dengan mekanisme pendampingan sosial. Pendampingan sosial akan menentukan strategi yang sangat menentukan keberhasilan program pemberdayaan masyarakat.
Dalam sebuah kajian lapangan yang dilakukan oleh Masrukin dkk tentang apa yang paling dibutuhkan dalam pemberdayaan masyarakat pacsa erupsi merapi: 1) Masyarakat serangkaian kegiatan pemberdayaan secara menyeluruh, antara kegiatan penyuluhan, pelatihan dan pendampingan. Karena selama ini, masyarakat telah mendapat penyuluhan, pelatihan dan bantuan, akan tetapi untuk program pendampingan yang dibutuhkan tidak diberikan. Akibatnya kurang mendukung pada keberlanjutan, peningkatan produktivitas dan pemasaran; 2) masyarakat membutuhkan lembaga koperasi yang memiliki badan hukum sebagai pusat usaha perekonomian untuk memenuhi kebutuhan permodalan, bahan baku, dan akses jaringan pemasaran; dan 3) masyarakat membutuhkan pelatihan secara periodik dan penguatan kembali kelompok siaga bencana di tingkat desa. ${ }^{13}$

Hasil penelitian ini kemudian dijawab oleh LSM dengan membentuk koperasi-koperasi di sekitar daerah Cangkringan dan sekitarnya. Beberapa koperasi yang didirikan adalah koperasi Kaliadem Sejahtera, koperasi Maju Makmur, KPT Mina Lestari, dan koperasi Mandiri. Koperasi ini menampung hasilhasil tangan masyarakat desa. Selain itu, melalui koperasi ini, pendampingan 
masyarakat terus dilakukan. Masyarakat pengolahan hasil bumi dan menjadikanya barang produksi yang layak dipasarkan. Kegiatan yang sifatnya pendampingan seperti ini akan membantu mengangkat perekonomian masyarakat.

Mengapa pendampingan sosial? Sumodiningrat menjelaskan bahwa pendampingan sosial akan memberdayakan kaum fakir miskin secara optimal. ${ }^{14}$ Merujuk pada Payne bahwa perinsip utama pendampingan sosial adalam "making the best of the clients's resources". 15 Dalam bahasa yang sederhana diistilahkan pendampingan sosial sebagai “membantu orang yang sedang berkesusahan agar mampu membantu dirinya sendiri". Dari penjelasan tersebut dapat ditarik satu benang merah bahwa pendampingan sosial memandang manusia sebagai subjek pembangunan, memiliki sistem yang aktif, dan memiliki potensi untuk diberdayakan.

Pendampingan sosial melibatkan banyak aktor di lapangan, baik dari pemerintah, swasta, dan partisipasi aktif dari masyarakat. Karena ini pendampingan sosial, maka tugas pekerja sosial (pendamping) hanyalah mendampingi atau sebagai pemberi stimulus, bukan sebagai penyembuh atau pemecah masalah (problem solver) secara langsung. Aktor utamanya tetap berada pada masyarakat yang mendapat pendampingan.

Dalam teori, Suharto merumuskan empat tahap pendampingan sosial, yakni: pemungkinan (enabling) atau fasilitasi, penguatan (empowering), perlindungan (protecting), dan pendukungan (supporting). (i) Pemungkinan atau Fasilitasi, merupakan fungsi yang berkaitan dengan pemberian motivasi dan kesempatan bagi masyarakat. Beberapa tugas pekerja sosial yang berkaitan dengan fungsi ini antara lain menjadi model (contoh), melakukan mediasi dan negosiasi, membangun konsensus bersama, serta melakukan manajemen sumber. (ii) Penguatan, fungsi ini berkaitan dengan pendidikan dan pelatihan guna memperkuat kapasitas masyarakat (capacity building).

Selanjutnya, (iii) perlindungan, fungsi ini berkaitan dengan interaksi antara pendamping dengan lembagalembaga eksternal atas nama dan demi kepentingan masyarakat dampingannya. Pekerja sosial dapat bertugas mencari sumber-sumber, melakukan pembelaan, menggunakan media, meningkatkan hubungan masyarakat, dan membangun jaringan kerja. Fungsi perlindungan juga menyangkut tugas pekerja sosial sebagai konsultan, orang yang bisa diajak berkonsultasi dalam proses pemecahan 
masalah. Dan terakhir, (iv) pendukungan, pendamping dituntut tidak hanya mampu menjadi manajer perubahan yang mengorganisasi kelompok, melainkan pula mampu melaksanakan tugas-tugas teknis sesuai dengan berbagai keterampilan dasar, seperti melakukan analisis sosial, mengelola dinamika kelompok, menjalin relasi, bernegosiasi, berkomunikasi, dan mencari serta mengatur sumber dana. ${ }^{16}$

Tabel 2 Lava Tour sebagai Bukti Pemberdayaan Masyarakat Kinahrejo

\begin{tabular}{|l|c|}
\hline \multicolumn{1}{|c|}{ Pekerjaan } & Jumlah \\
\hline Tukang Ojek & $\mathbf{2 6}$ \\
\hline Usaha Warung & 1 \\
\hline Parkir & 1 \\
\hline $\begin{array}{l}\text { Penjaga Retribusi Masuk } \\
\text { ke Wisata }\end{array}$ & 1 \\
\hline Penjaga Toilet Wisata & 16 \\
\hline
\end{tabular}

Sumber: Waryono, dkk (2012)

Dalam keterbatasan, melalui pendampingan yang dilakukan oleh Pemkab Sleman yang bekerjasama dengan BPPTK Sleman (Badan Penyelidikan dan Pengembangan Kegunungapian), masyarakat Kinahrejo mendapatkan pengetahuan tentang manajemen pengelolaan desa wisata dan vulkanologi. Masyarakt berperan aktif dalam membangun objek wisata Lava Tour.
Munculnya objek wisata ini yang kemudian menjadi berkah bagi sebagian masyarakat Kinahrejo.

Pendampingan sosial dalam pemberdayaan masyarakat menjadi salah satu variabel penting dalam pembangunan di desa (rural development). Walau masih banyak pihak yang meragui pencapaian variabel dalam pembangunan, akan tetapi yang paling idel setelah terjadi bencana dan masyarakat berada pada titik nol, pendampingan sosial menjadi solusinya. Pendampingan sosial yang telah dilakukan dibebrapa tempat terus berupaya meningkatkan harkat dan martabat lapisan masyarakat yang dalam kondisi sekarang tidak mampu untuk melepaskan diri dari perangkap kemiskinan dan keterbelakangan. Dengan kata lain pekerjaan memberdayakan adalah memampukan serta memandirikan masyarakat.

\section{Sumbangsih Perempuan Pasca Erupsi}

\section{Merapi}

Apabila kita yakin akan kebenaran ramalam dua futurolog John Naisbeth dan Patricia Aburdens dalam buku Megatrends 2000 yang meramalkan bahwa abad ke-21 adalah abadnya wanita, maka seyogyanya wanita di Indonesia menyambut dengan optimisme. Dikaitkan dengan kasus ini, apakah perempuan lereng merapi menjadi 


\section{Ashadi Cahyadi \\ BENEANA, PERLINDLINGAN SDSIAL, DAN PEREMPLAN}

subjek pendukung pembangunan pasca erupsi merapi?Gambaran umum perempuan Indonesia dalam banyak kondisi, seringkali diposisikan sebagai objek atau mahluk yang butuh perhatian lebih.

Demartoto menjelaskan gambaran umum perempuan Indonesia yang sering dimarjinalisasi baik oleh kebijakan pemerintah, keyakinan, tradisi, kebiasaan sehari-hari, atau karena asumsi ilmu pengetahuan sekalipun. ${ }^{17}$ Kemudian, subordinasi yang memiliki emosional dan irrasional sehingga tidak mampu untuk memimpin. Anggapan lainnya adalah perempuan itu lemah dan cenderung mendapat perlakuan kekerasan (violance). Pada penjelasan seperti ini, perempuan berada pada titik yang paling dipojokkan. Bagaimana perspektif bencana (disaster) memandang perempuan?

IDNDR atau United Nation's International Decade for Natural Disaster Reduction dalam deklarasi tahun 1995 telah menempatkan perempuan dan anakanak sebagai "key to prevention" dalam mengurangi dampak bencana. Hal ini karena anak-anak dan perempuan adalah entitas yang cukup rentan terhadap bencana. Partinidalam kajianya juga menjelaskan bahwa perempuan adalah kaum yang rentan dan paling dominan menjadi korban saat bencana. Secara fisik, perempuan memiliki kondisi yang relatif lebih lemah dibandingkan lelaki, sehingga ketika ada bencana alam, perempuan kalah sigap dari lelaki. Terlebih perempuan memiliki vulnerabilitas yang lebih tinggi terhadap bencana; perempuan mendapat peran ganda (double bureden) menyelematkan anak dan lansia. ${ }^{18}$

Data yang dipaparkan oleh Lorena Aguilar, seorang Senior Gender Advisor untuk IUCN (National Union for Conservation of Nature) menjelaskan pada bencana tsunami 2004 silam yang melanda Aceh, sekitar 70\%-80\% korban yang meninggal adalah perempuan. Sedangkan korban dipihak perempuan pada bencana erupsi merapi, yang penulis himpun dari http://www.slemankab.go.id, berjumlah 83 orang dari total 230 orang atau sekitar 36\%. Sekitar 58 dari 83 perempuan itu berumur $>50$ tahun (lansia). Jumlah ini lebih sedikit jika dibanding dengan korban dari pihak laki-laki yang berjumlah 117 orang. Sedangkan untuk 34 orang lagi, menurut data yang dikeluarkan tahun 2010 bulan November ini, belum diotopsi. Pelajaran dari bencana erupsi merapai ini adalah apakah pengurangan jumlah perempuan yang turun drastis dari bencana-bencana yang lalu mengindikasikan perempuan telah dan lebih sigap terhadap bencana. 


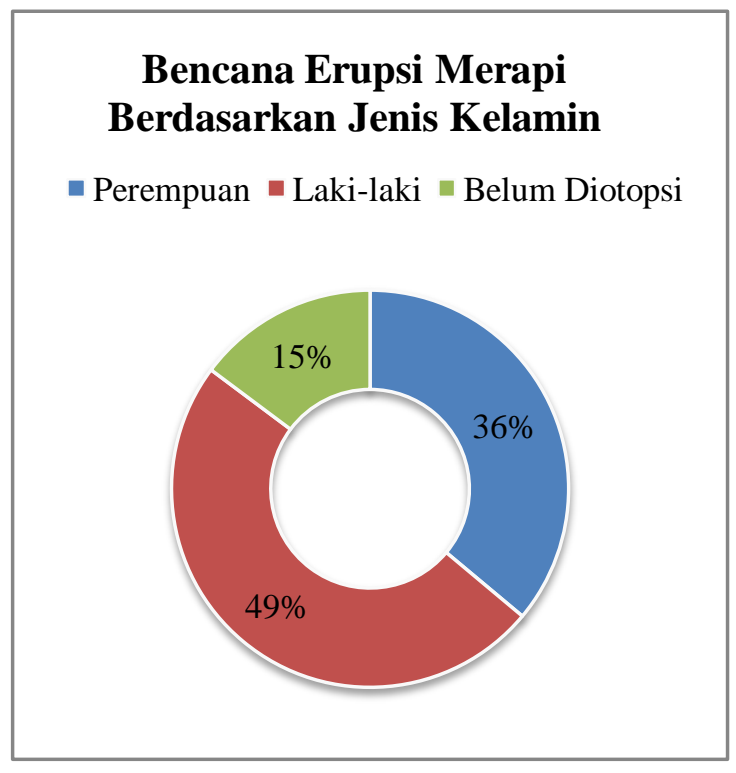

Di balik kerentanan sosial, ekonomi, dan budaya, perempuan terbukti efektif dalam penanggulangan bencana, baik saat pencegahan maupun masa tanggap darurat. Pengorganisasian yang dilakukan oleh perempuan sangat bermanfaat untuk mengurangi risiko bencana. Perempuan lebih sering berada di rumah dan keberadaanya hampir selalu ada di lingkungan sekitar wilayah bencana, sehingga penyebaran informasi melalui perempuan sangatlah efektif. Data di atas juga mulai menunjukkan, bencana erupsi merapi telah mengubah perempuan menjadi tangguh dalam menghadapi kondisi yang sulit dan kritis. Misalnya dalam data disebutkan ada sekitar 49\% atau 117 korban dari pihak laki-laki, maka perempuan yang telah kehilangan suami akan menafkahi keluarga agar dapat bertahan hidup (survive). Shiva menjelaskan bahwa apabila perempuan diberdayakan, mereka akan menjadi motor penggerak (agent of change) yang dapat merespon perubahan lingkungan.

Penelitian yang dilakukan oleh Waryono, dkk tentang Resilience Perempuan dalam Bencana Alam Merapi di Desa Kinahrejo, memperkuat pandangan Shiva bahwa perempuan sebelum terjadi erupsi Merapi atau bahkan jauh sebelumnya, perempuanperempuan di Kinahrejo terlibat secara aktif dalam beragam aktivitas. Misalnya, bagi peternak sapi, beberapa aktivitas seperti mugut (mencari rumput), membersihkan kandang, sampai memerah dan menjual susunya, dapat dilakukan oleh perempuan. Perempuan-perempuan di Kinahrejo cukup produktif, dalam arti, dapat menghasilkan uang dari kegiatan memelihara ternaknya. Bagi perempuan di Kinahrejo, bekerja di luar rumah seperti tersebut adalah hal biasa. Mereka tidak membedakan antara pekerjaan domestik dengan pekerjaan publik. Ini sebagai indikasi bahwa tidak ada persoalan gender dalam pekerjaan. Namun erupsi Merapi tahun 2010 telah mematikan sejumlah hewan ternak, kurang lebih 285 ternak, sehingga dengan matinya hewan ternak itu berarti juga mematikan pekerjaan warga, termasuk para perempuan. 
Setelah terjadi erupsi Merapi, program-program penanggulangan bencana juga mengikutsertakan perempuan dalam proses recovery. Perempuan sangat diandalkan kemampuannya dalam merespon perubahan dan kemampuan untuk beradaptasi ini merupakan sumber daya yang dapat dimanfaatkan untuk perencanaan. Hasil penelitian Waryono dkk juga menggambarkan bagaimana keikutsertaan perempuan dalam kegiatan di dapur umum sebagai sarana pengelolaan bantuan untuk kepentingan bersama. "Kita membuat jadwal di dapur, mas. Ngak semua masak, ada pekerjaan lain. Satu orang dapat jatah di dapur tiga kali seminggu". Dalam keadaan seperti ini, dapur yang diidentikkan dengan domestifikasi perempuan ternyata justru menampakkan eksistensi perempuan yang sesungguhnya. Penanganan dapur umum merupakan kegiatan pelayanan publik yang mensyaratkan kemampuan pengorganisasian perempuan sehingga tidak bisa hanya dilihat sebagai kegiatan domestik belaka. Dapur umum bagi eksistensi perempuan tidak saja menyiratkan peran mereka dalam pemulihan paska bencana. Di dalam konsep ini juga terbangun konsep pengorganisasian yang khas ala perempuan.

Peranan perempuan dalam bencana juga diketahui melalui survei tahun 2013 di daerah Sleman dan Bantul, yang menjelaskan bahwa $88,8 \%$ perempuan di Sleman responsif pada daerahnya yang rawan bencana, sedangkan di Bantul $65,4 \%$ perempuan meresponnya. Begitu juga dengan tanda-tanda akan adanya bencana, 83,8 \% perempuan di Sleman mengetahuinya. data ini makin menguatkan akan peran utama perempuan dalam pengurangan risiko bencana. Secara naluri, masyarakat yang tinggal di daerah rawan bencana memilik tingkat respon yang lebih tinggi terhadap bencana.

Tabel 3 Respon Perempuan Tanggap

Bencana

\begin{tabular}{|l|c|c|}
\hline \multicolumn{1}{|c|}{ Pengetahuan } & Sleman & Bantul \\
\hline $\begin{array}{l}\text { Mengetahui } \\
\text { daerahnya rawan } \\
\text { bencana }\end{array}$ & 88,8 & 65,4 \\
\hline $\begin{array}{l}\text { Tanda-tanda akan } \\
\text { bencana }\end{array}$ & 83,8 & 30,3 \\
\hline
\end{tabular}

Sumber: Partini, dkk(2014).

Ketangguhan perempuan terus berlanjut setelah pasca erupsi Merapi. Perempuan-perempuan lereng merapi sadar pada kondisi ekonomi yang sedang dialami keluarga. Sebelum erupsi merapi, 
74,6\% perempuan di sekitar lereng Merapi memiliki usaha sendiri, dan 25,4\% bekerja secara kelompok. Bencana merapi telah menghancurkan usaha-usaha perempuan tangguh ini. Dalam data Partini, et, al., (2014) juga dijelaskan bahwa 60\% tempat kerja hancur. Karena itu, lahir usahausaha baru yang dipelopori oleh perempuan, baik dibentuk secara kelompok ataupun individu. Dari data survei di Sleman pasca erupsi Merapi, sekitar 40,8\% perempuan memulai usaha secara mandiri, sedangkan 59,2 \% dilakukan secara kelompok.

Tabel 4 Upaya Bangkit dan Kepemilikan Usaha Perempuan Pasca Erupsi

\begin{tabular}{|l|c|c|}
\hline $\begin{array}{c}\text { Sifat } \\
\text { Kepemilikan }\end{array}$ & $\begin{array}{c}\text { Upaya } \\
\text { Bangkit }\end{array}$ & $\begin{array}{c}\text { Kepemilikan } \\
\text { Usaha }\end{array}$ \\
\hline Mandiri & $53,9 \%$ & $40,8 \%$ \\
\hline Kelompok & $55,3 \%$ & $59,2 \%$ \\
\hline
\end{tabular}

Sumber: Partini, dkk (2014)

Kebangkitan perempuan pasca erupsi merapi tidak hanya bermanfaat untuk menunjang pemenuhan ekonomi keluarga semata, tetapi juga pada pengembangan diri perempuan itu sendiri. Ditinjau dari sudut pandang psikologi, perempuan yang memiliki usaha sendiri, penghasilan sendiri, telah menjadi pribadi yang lebih berdaya dan melepas ketergantungan ekonomi dari 108 bantuan-bantuan luar termasuk laki-laki. Usaha di bidang ekonomi seperti inilah yang mampu memunculkan self-esteem (harga diri) dan menguatkan eksistensi diri dalam keluarga dan bermasyarakat.

\section{Kesimpulan}

Pembangunan dan bencana menjadi ironi tersendiri dalam kehidupan umat manusia. Bencana besar yang melanda Yogyakarta dan sekitarnya tahun 2010 lalu telah menggambarkan secara tragis betapa pembangunan digalakkan dan kemudian dihancurkan dalam sebuah bencana, kemudian pembangunan digalakkan lagi. Sampai kapan dua siklus ini tarik menarik? Seperti mempermainkan manusia dan sejarah peradaban di kaki merapi. Pembangunan dan bencana. Membutuhkan seluruh upaya anak manusia untuk bersiaga, me-recovey, dan membuat program-program jangka panjang. Pemberdayaan masyarakat melalui pendampingan sosial menjadi strategi yang paling idel dan rasional ketika masyarakat berada pada kondisi lower-lower class, berbulan-bulan menggantungkan nasib pada negara dan swasta. Bersama aktor-aktor ini, masyarakat mencoba kembali mencari asa, meniti kembali jalan hidup melalui program-program yang telah dirancang khusus oleh pemerintah, baik berupa 
penerimaan uang Rp. 5.000,- perhari ataupun melalui 20 paket program padat karya.

Pembangunan dan bencana telah menambah derita perempuan-perempuan tangguh. Meraka sudah cukup dipandang rendah oleh pembangunan, tetapi bencana ikut menenggelamkan mereka. Perempuan-perempuan tangguh tidak berputus asa. Kondisi yang berat, ibarat "gunung merapi di atas pundak mereka", mereka lawan dengan turut membantu program recovery, memasak di dapur, membagikan sembako secara teratur setiap hari. Merakamentransformasi diri, menyembuhkan dirinya sendiri, memberi pengaruh pada lingkungan keluarga, tetangga-tetangga terdekat dan terus meluas ke daerah-daerah lain. Mereka berusaha bangkit dengan mencari terobosan untuk hidup, agar tidak tergantung pada bantuan dan kedermawanan orang lain. Karena bagi perempuan-perempuan tangguh ini,hidup dari usaha sendiri lebih membahagiakan, daripada menerima bantuan.

\section{Referensi}

\begin{tabular}{l} 
1Mengurai Kemiskinan Paska Bencana \\
Merapi. Diakses dari \\
http://sosbud.kompasiana.com. \\
\multicolumn{3}{c}{ 2Affeltranger, B. Hidup Akrab dengan Bencana: } \\
Sebuah Tinjauan Globa tentang Inisiatif-Inisiatif
\end{tabular}

Pengurangan Bencana. (Jakarta: Masyarakat Peduli Bencana Indonesia, 2006). hlm. 18.

${ }^{3}$ Goel, S. L. Ensyclopaedia of Disaster Management: Disaster Management Policy and Administration. Vol 1. (India: Deep \& Deep Publiction, 2006). hlm. 293.

4Salim, A. Perubahan Sosial: Sketsa Teori dan Refleksi Metodologi Kasus Indonesia. (Yogyakarta: Tiara Wacana, 2002). hlm. 20.

5Salim, A. Perubahan Sosial: Sketsa Teori dan Refleksi... hlm. 15-17.

6Suharto, E. Membangun Masyarakat Memberdayakan Rakyat. (Bandung: Refika Aditama, 2005). hlm. 153.

7Pendangan residual menyatakan bahwa pelayanan sosial baru perlu diberikan hanya apabila kebutuhan individu tidak dapat dipenuhi dengan baik oleh lembaga-lembaga yang ada di masyarakat. Perspektif residual sangat dipengaruhi oleh ideologi konservatif yang cenderung menolak perubahan (Parsons et, al., 1994; Zastrow, 2000). Dalam hal ekonomi, penganut konservatif ini melihat bahwa pemerintah tidak perlu mengintervensi pasar. Ekonomi pasar bebas lebih baik adalah cara yang baik untuk mempercepat laju kemakmuran masyarakat. Sedangkan pandangan institusional melihat sistem dan usaha kesejahteraan sosial sebagai fungsi yang tepat dan sah dalam masyarakat modern. Pandangan ini banyak dipengaruhi oleh ideologi liberal yang percaya bahwa perubahan pada umumnya baik dan senantiasa membawa perubahan (Parsons et, al., 1994; Zastrow, 2000). Pandangan ini sangat mendukung model welfare state welfare state yang bersifat universal. Program-program pemerintah, termasuk program kesejahteraan sosial dipandang penting untuk memenuhi kebutuhan dasar manusia secara luas dan berkelanjutan.

8Budiman, A. Teori Pembangunan Dunia

Ketiga. (Jakarta: PT Gramedia Pustaka Utama, 2000). hlm. 2-8.

9Salim, A. Perubahan Sosial: Sketsa Teori dan Refleksi... hlm. 93.

${ }^{10}$ Chambers dalam Kartasasmita, G. Pembangunan Untuk Rakyat. (Jakarta: Pustaka Gramedia, 1996). hlm. 76

${ }^{11} \mathrm{Hatu}, \quad$ R. H. Pemberdayaan dan Pendampingan Sosial dalamMasyarakat: SuatuKajian Teortis. JurnalInovasi,Vol. 7, No. 4, 2010. hlm. 240-254. 
12Ife, J. Community Development: Creating Community Alternatives, Vision, Analysis and Practice. (Australia: Longman, 1995). hlm. 61-64.

${ }^{13}$ Masrukin., Sugito, T., Suswanto, B., dan Sabiq, A. Model Pemberdayaan Masyarakat Pascaerupsi Gunung Merapi di Jawa Tengah dan Yogyakarta. Jurnal Komunitas, Vol. 5, No. 2, 2012. hlm. 172-184.

14Sumodiningrat, G. 2009. Mewujudkan Kesejahteraan Bangsa Menanggulangi Kemiskinan dengan Prinsip Pemberdayaan Masyarakat. (Jakarta : PT. Alex Media Komputindo, 2009). hlm. 106.

15Peyne, M. Social Care in The Community. (London: McMillian, 1986). hlm. 26

16 Suharto, E. Membangun Masyarakat

Memberdayakan Rakyat... hlm. 93-97.

17Demartoto, A. 2009. Kebutuhan Praktis dan Strategi Gender. (Surakarta: Sebelas Maret University Press, 2009). hlm. 48-49.

18Partini., Kusumasari, B., \& Suyatna, H. Strategi Perempuan Tangguh Bencana. (Yogyakarta: Gava Media, 2014). hlm. 1-3. 